\title{
PENGGUNAAN TEPUNG RUMPUT LAUT Eucheuma cottonii PADA PEMBUATAN BERAS ANALOG DARI TEPUNG MODIFIED CASSAVA FLOUR (MOCAF)
}

\section{The Use of Eucheuma cottonii Flour in the Processing of Rice Analogues from Modified Cassava Flour (Mocaf)}

\author{
Agusman $^{1 *}$, Siti Nurbaity Kartika Apriani ${ }^{1}$, dan Murdinah ${ }^{1}$ \\ 1 Balai Besar Penelitian dan Pengembangan Pengolahan Produk dan Bioteknologi Kelautan dan Perikanan, \\ JI.K.S. Tubun Petamburan VI, Jakarta Pusat, Indonesia \\ * Korespondensi Penulis: mr.agusman@gmail.com \\ Diterima: 21 Februari 2014; Disetujui: 6 Mei 2014
}

\begin{abstract}
ABSTRAK
Penelitian penggunaan tepung rumput laut Eucheuma cottoni pada pembuatan beras analog dari tepung modified cassava flour (mocaf) menggunakan teknologi granulasi telah dilakukan. Tepung rumput laut yang ditambahkan pada pembuatan beras analog adalah $0,3,5$, dan $7 \%$ dari berat tepung mocaf. Beras analog yang dihasilkan diamati karakteristik mutunya yang meliputi rendemen, sensori, densitas kamba, derajat putih, komposisi proksimat, serat pangan, dan iodium. Hasil penelitian menunjukkan bahwa penambahan tepung rumput laut tidak berpengaruh terhadap densitas kamba dan komposisi proksimat beras analog tetapi berpengaruh pada derajat putih, rendemen, serat pangan, dan iodium. Berdasarkan uji kesukaan (hedonik), beras analog yang dibuat dari tepung mocaf dengan tepung rumput laut sebesar $5 \%$ lebih disukai panelis dibandingkan dengan perlakuan lain. Karakteristik beras analog yang dihasilkan memiliki rendemen $99 \%$, densitas kamba $0,57 \mathrm{~g} / \mathrm{ml}$, derajat putih $17,70 \%$, kadar air $8,76 \%$, kadar abu $1,96 \%$, kadar protein $0,86 \%$, lemak $0,15 \%$, serat pangan $49,76 \%$, dan iodium $24,98 \mu \mathrm{g} / \mathrm{g}$. Beras analog berbentuk silinder berukuran panjang 3-5 mm dan belum menyerupai bentuk beras.
\end{abstract}

KATAKUNCl: mocaf, tepung rumput laut, formula, beras analog

\begin{abstract}
Research on the use of Eucheuma cottonii flour in the processing of rice analogues from modified cassava flour (mocaf) flour by applying granulation technology has been conducted. Eucheuma cottonii flour addition was varied i.e. 0, 3, 5 and 7\% from mocaf flour wieght. Quality parameters of rice analogues observed were yield, sensory, bulk density, whiteness degree, proximat composition, dietary fiber and iodium. Results showed that seaweed flour addition was not significant on bulk density, and proximat composition rice analogues but significant on whiteness degree, yield, dietary fiber, and iodium. According to hedonic sensory evaluation, rice analogous made of mocaf flour with $5 \%$ seaweed flour was preferred compared to other treatments. The quality characterisistics of this rice analogous were $99 \%$ yield, $0.57 \mathrm{~g} / \mathrm{ml}$ bulk density, $17.70 \%$ whiteness degree, $8.76 \%$ moisture content, $1.96 \%$ ash content, $0.86 \%$ protein content, $0.15 \%$ fat content, $49.76 \%$ dietary fiber, $24.98 \mu \mathrm{g} / \mathrm{g}$ iodine. Shape of rice analogues was silindric with 3-5 $\mathrm{mm}$ length and has not been approaching to rice shape yet.
\end{abstract}

KEYWORDS: mocaf, seaweed flour, formula, rice analogues

\section{PENDAHULUAN}

Beras analog atau beras tiruan merupakan beras yang terbuat dari bahan-bahan seperti umbi-umbian dan serealia yang bentuk maupun komposisi gizinya mirip dengan beras (Samad, 2003). Pengembangan beras analog sangat penting sebagai bentuk diversifikasi bahan pangan yang merupakan makanan pokok bangsa Indonesia. Penelitian mengenai pembuatan beras analog yang terbuat dari tepung lokal seperti tepung jagung, tepung ubi, tepung singkong, tepung sorgum, maupun sagu telah dilakukan, namun formulasi pembuatan beras analog dengan penambahan tepung rumput laut sebagai 
sumber serat pangan belum banyak dilakukan. Kendala utama dalam pengembangan beras analog selama ini yaitu aspek penerimaan produk dalam hal bentuk dan warna yang berbeda dengan beras pada umumnya, sehingga dapat mempengaruhi psikologis konsumen dalam menentukan pilihannya terhadap beras analog tersebut (Widowati et al., 2008). Beras analog dengan sifat fungsional khusus memiliki prospek yang sangat baik, seperti produk beras analog yang kaya serat dapat bermanfaat untuk mengurangi kolesterol, mencegah obesitas atau untuk penderita diabetes yang perlu mengkonsumsi karbohidrat rendah kalori (Budijanto \& Yuliyanti, 2012) dan beras analog yang diperkaya dengan protein dapat bermanfaat untuk mengurangi defisiensi protein (Kato, 2006; Ichikawa \& Chiharu, 2007). Di samping itu beras analog juga dikembangkan untuk menambah mineral dan vitamin pada beras (Moretti et al., 2006; Li et al., 2008; Ashong et al., 2012).

Rumput laut jenis E.cottonii termasuk dalam kelas Rhodophyceae (ganggang merah) penghasil karaginan. Menurut Astawan et al. (2004), tepung rumput laut $E$. cottonii mengandung serat pangan total $91,3 \%$ berat kering dan iodium sebesar $19,4 \mu \mathrm{g} / \mathrm{g}$ berat kering. Penggunaan rumput laut $E$. cottonii dalam pengembangan beras analog dapat menghasilkan produk yang kaya serat pangan. Penelitian pembuatan beras analog menggunakan bahan dasar beras menir dengan menambahkan tepung rumput laut $E$. cottonii menggunakan teknologi ekstrusi sudah pernah dilakukan oleh Muslikatin (2012).

Salah satu bahan pangan yang berpotensi digunakan sebagai sumber karbohidrat adalah modified cassava flour (mocaf). Mocaf merupakan produk turunan dari tepung singkong yang menggunakan prinsip modifikasi sel singkong secara fermentasi (Subagio, 2006). Mocaf adalah salah satu bahan pangan lokal yang kaya karbohidrat sehingga dapat dijadikan bahan pangan alternatif yang dapat dikembangkan dalam upaya diversifikasi pangan. Dewi (2012) telah memanfaatkan mocaf sebagai bahan dasar pembuatan beras analog dengan teknologi ekstrusi. Penelitian ini bertujuan untuk mendapatkan formula beras analog berbahan dasar tepung mocaf dengan tepung rumput laut $E$. cottonii dan mempelajari karateristik mutu beras analog yang dihasilkan.

\section{BAHAN DAN METODE}

\section{Bahan dan Alat}

Bahan yang digunakan untuk pembuatan tepung rumput laut adalah $E$. cottonii kering yang dipanen umur 45 hari yang diperoleh dari Denpasar Bali.
Bahan-bahan untuk pembuatan beras analog dalam penelitian adalah tepung rumput laut $E$. cottonii, tepung mocaf yang diperoleh dari PT. Multi Usaha Wisesa, dan air mineral.

Alat yang digunakan untuk pembuatan beras analog diantaranya adalah timbangan, loyang, baskom, saringan, penangas air, kompor, panci, pencentak beras analog, pengukus, dan pengering. Pencetak patilo berupa meja bertingkat bagian atas terbuat dari bahan stain steel berlubang-lubang dengan diameter 3-5 mm untuk mencetak dan bagian bawah terbuat dari kayu untuk menampung hasil cetakan, sedangkan tipe kabinet dengan konstruksi berupa kotak bertingkat, bagian bawah untuk pengeringan dan bagian atas untuk pengembalian sirkulasi udara.

\section{Metode}

\section{Pembuatan tepung Eucheuma cottonii}

Rumput laut $E$. cottonii dicuci hingga bersih kemudian dicacah kecil-kecil. Rumput laut yang telah dicacah dikeringkan pada suhu $40^{\circ} \mathrm{C}$ selama 10 jam hingga kadar air di bawah $10 \%$ dengan alat pengering tipe kabinet. Rumput laut yang telah kering digiling menjadi tepung dan diayak menggunakan saringan 100 mesh. Tepung rumput laut yang dihasilkan dianalisis komposisi proksimat (AOAC, 2004) dan serat pangan (Asp et al., 1983).

\section{Pembuatan beras analog}

Pembuatan beras analog dalam penelitian ini menggunakan teknologi granulasi seperti yang dilakukan oleh Prasetia (2009). Pada pembuatan beras analog, pertama-tama tepung mocaf dengan tepung rumput laut dicampur hingga rata. Konsentrasi tepung rumput laut yang digunakan untuk pembuatan beras analog dalam penelitian ini adalah $0,3,5$, dan $7 \%$ dari berat mocaf yang digunakan. Penentuan konsentrasi penambahan tepung rumput laut mengacu pada Muslikatin (2012). Campuran bahan tersebut ditambah air $20 \%$ dari berat tepung total (tepung mocaf dan tepung rumput laut) diaduk hingga terbentuk adonan semibasah, selanjutnya dilakukan pembutiran dengan menggunakan alat pencetak beras analog (pencetak patilo) sehingga diperoleh butiran-butiran adonan yang berbentuk silinder berukuran 3-5 $\mathrm{mm}$ dan menyerupai pelet. Butiran-butiran adonan kemudian dikukus selama 6 menit pada suhu 90$100{ }^{\circ} \mathrm{C}$ hingga campuran tepung mocaf dan tepung rumput laut mengalami gelatinisasi yang ditandai dengan adanya perubahan campuran bahan yang sebelumnya berwarna putih menjadi bening. Setelah dikukus butiran-butiran tersebut didinginkan pada 
kondisi suhu ruang selama 20 menit, kemudian dikeringkan menggunakan alat pengering tipe kabinet pada suhu $40^{\circ} \mathrm{C}$ selama $10 \mathrm{jam}$. Beras analog yang telah kering disortasi untuk mendapatkan bentuk dan ukuran yang sama.

\section{Pemasakan beras analog}

Pemasakan beras analog dengan cara merendam beras analog dalam air (perbandingan 1:2 dari berat beras analog) selama 10 menit. Setelah itu, beras yang telah direndam ditiriskan lalu dikukus dengan alat pengukus selama 11 menit.

\section{Rancangan Penelitian}

Penelitian ini menggunakan Rancangan Acak Lengkap dengan uji lanjut Duncan. Sedangkan untuk analisis sensori menggunakan Kruskal Wallis dengan uji lanjut Dunn test. Analisis data dibantu dengan menggunakan SPSS-IBM 18. Setiap perlakuan percobaan dilakukan pengulangan 3 kali.

\section{Analisis}

Beras analog yang diperoleh dihitung rendemennya dan dianalisis sifat fisiknya yang meliputi densitas kamba (Wirakartakusumah et al., 1992), derajat putih yang diamati menggunakan whiteness meter Kett Electric Laboratory C-100-3, waktu tanak (Juliano, 1985 dalam Prasetia, 2009) dan kandungan proksimat (AOAC, 2004). Pengujian sensori terhadap beras analog mentah dan matang dilakukan terhadap kesukaan dengan menggunakan uji hedonik dengan skor 1-7 dengan kriteria 1 (sangat tidak suka); 2 (tidak suka); 3 (agak tidak suka); 4 (netral); 5 (agak suka); 6 (suka) dan 7 (sangat suka). Pemilihan formula beras analog terbaik berdasarkan uji sensori, analisis kandungan serat pangan (Asp et al., 1983), dan kandungan iodium (AOAC, 2004).

\section{HASIL DAN PEMBAHASAN}

\section{Komposisi Proksimat Tepung Rumput Laut}

Hasil analisis komposisi proksimat tepung rumput laut $E$. cottoniyang digunakan pada pembuatan beras analog dapat dilihat pada Tabel 1. Kandungan abu tepung rumput laut adalah sebesar $14,81 \%$ (bk). Kandungan abu yang besar pada rumput laut mengindikasikan tingginya mineral yang terdapat pada rumput laut seperti iodium, natrium, dan kalium.

Dari Tabel 1 diketahui bahwa kandungan karbohidrat dari tepung rumput laut mencapai $69,99 \%$ (bk). Menurut Astawan et al. (2005) kandungan karbohidrat rumput laut adalah serat makanan yang mampu mengikat kolestrol dalam darah. Kandungan protein tepung rumput laut cukup tinggi yaitu sebesar $7,91 \%$ (bk). Hal ini menandakan tepung rumput laut E. cottonii tidak hanya sebagai sumber iodium dan serat pangan, namun juga protein. Kandungan lemak tepung rumput laut $E$. cottonii adalah $0,41 \%$ (bk) hal ini menunjukkan bahwa kandungan lemak tepung rumput laut rendah.

Hasil analisis serat pangan menunjukkan bahwa tepung rumput laut $E$. cottonii pada penelitian ini mempunyai kandungan serat pangan sebesar $66,40 \%$ (bk). Tepung rumput laut $E$. cottonii mengandung serat pangan total lebih tinggi daripada tepung rumput laut Gelidium sp. dan Sargassum sp. masing-masing adalah 64,43; 53,05; dan 56,00\% (Herpandi et al., 2006). Kandungan serat pangan tepung rumput laut E. cottonii yang digunakan dalam penelitian ini tidak jauh berbeda dengan hasil analisis Herpandi et al. (2006). Serat pangan merupakan karbohidrat kompleks di dalam bahan pangan yang tidak dapat dicerna oleh enzim-enzim pencernaan manusia. Serat pangan ini merupakan komponen dari jaringan tanaman yang tahan terhadap proses hidrolisis oleh

Tabel 1. Komposisi proksimat tepung rumput laut E. cottonii

Table 1. Proximate composition of E. cottonii flour

\begin{tabular}{lc}
\hline \multicolumn{1}{c}{ Komposisi/Composition } & $\begin{array}{c}\text { Tepung Rumput Laut/ } \\
\text { Seaweed }\end{array}$ \\
\hline Kadour (bk/db)
\end{tabular}


enzim dalam lambung dan usus kecil (Winarno, 2008). Tepung rumput laut sebagai sumber serat pangan dapat ditambahkan dalam produk pangan untuk memperkaya serat.

Tepung mocaf yang digunakan sebagai bahan baku beras analog mengandung protein sebesar $2,24 \%$ (bk); lemak 1,20\% (bk); karbohidrat $87,02 \%$ (bk); dan serat pangan $3,12 \mathrm{~g} / 100 \mathrm{~g}$ (bk). Tepung mocaf mengandung karbohidrat cukup tinggi, sedangkan kandungan komponen non patinya seperti kadar protein, lemak, dan serat pangan cukup rendah. Kandungan serat pangan tepung mocaf cukup rendah, demikian juga tepung mocaf yang diproduksi oleh koperasi Loh Jenawi, Trenggalek (Dewi, 2012). Oleh karena itu, beras analog berbahan dasar mocaf mengandung serat yang rendah. Tepung rumput laut yang digunakan pada penelitian ini memiliki kandungan serat pangan yang lebih tinggi daripada tepung mocaf. Sehingga penambahan tepung rumput laut dalam pembuatan beras analog berbahan baku tepung mocaf diharapkan dapat meningkatkan kandungan serat pangannya.

\section{Sifat Fisik Beras Analog}

Sifat fisik beras analog meliputi rendemen, derajat putih dan densitas kamba dapat dilihat pada Tabel 2 . Rendemen beras analog yang dihasilkan berkisar antara $98-100 \%$. Hasil analisis statistik menunjukkan bahwa penambahan tepung rumput laut berpengaruh terhadap rendemen beras analog dan terlihat sedikit peningkatan rendemen dari beras analog seiring dengan penambahan tepung rumput laut. Kandungan karaginan pada tepung rumput laut juga dapat berfungsi sebagai bahan penstabil dan pengikat yang menyatukan komponen lain sehingga mencegah terjadi kehilangan selama proses pembuatan beras (Herawati \& Widowati, 2009; Mishra et al., 2012).
Secara visual beras asli yang biasa dikonsumsi adalah berwarna putih maka diharapkan beras analog memiliki warna putih yang mendekati warna beras asli, sehingga tidak mengurangi persepsi konsumen terhadap beras analog (Mishra et al., 2012). Namun demikian, beberapa beras analog juga sudah mulai diterima walaupun warna beras yang dihasilkan tidak putih.

Beras analog yang dihasilkan dalam penelitian ini memiliki nilai derajat putih berkisar antara 15,1-22,2\% yaitu semakin tinggi nilai derajat putih semakin putih beras analog yang dihasilkan. Hasil analisis statistik menunjukkan bahwa penambahan tepung rumput laut berpengaruh sangat nyata terhadap parameter derajat putih beras analog, dengan nilai derajat putih tertinggi diperoleh pada perlakuan tanpa penambahan tepung rumput laut. Penambahan tepung rumput laut menyebabkan derajat putih beras analog yang dihasilkan menjadi turun. Derajat putih mocaf dari hasil analisis adalah $85,40 \%$ lebih tinggi daripada derajat putih tepung rumput laut sebesar $59,80 \%$. Dengan demikian maka semakin besar jumlah tepung rumput laut yang ditambahkan dalam pembuatan beras analog diduga dapat menyebabkan nilai derajat putih beras analog semakin menurun. Menurut Diehl (1988), dalam pembuatan beras analog jika menginginkan warna yang putih perlu ditambahan bahan yang dapat memutihkan pati seperti titanium.

Informasi densitas kamba suatu produk dapat digunakan sebagai acuan dalam menentukan besarnya volume yang dibutuhkan persatuan bobot produk tersebut (Herawati \& Widowati, 2009). Densitas kamba tidak hanya berkaitan dengan volume beras analog per satuan berat tapi juga mempengaruhi volume yang disajikan kepada konsumen terhadap satuan berat.

Tabel 2. Hasil analisis rendemen, derajat putih, dan densitas kamba beras analog

Table 2. Results analysis of yield, whiteness degree and bulk density of rice analogues

\begin{tabular}{cccc}
\hline $\begin{array}{c}\text { Penambahan Tepung } \\
\text { Rumput Laut/ } \\
\text { Seaweed Flour Addition }\end{array}$ & $\begin{array}{c}\text { Rendemen/ } \\
\text { Yield (\%) }\end{array}$ & $\begin{array}{c}\text { Derajat Putih/ } \\
\text { Whiteness } \\
\text { Degree (\%) }\end{array}$ & $\begin{array}{c}\text { Densitas } \\
\text { Kamba/ } \\
\text { Bulk Density } \\
\text { (g/ml) }\end{array}$ \\
\hline $0 \%$ & $98^{\mathrm{a}}$ & $22.20^{\mathrm{b}}$ & $0.53^{\mathrm{a}}$ \\
$3 \%$ & $99^{\mathrm{ab}}$ & $15.40^{\mathrm{a}}$ & $0.53^{\mathrm{a}}$ \\
$5 \%$ & $99^{\mathrm{ab}}$ & $17.70^{\mathrm{a}}$ & $0.57^{\mathrm{a}}$ \\
$7 \%$ & $100^{\mathrm{bc}}$ & $15.10^{\mathrm{a}}$ & $0.55^{\mathrm{a}}$ \\
\hline
\end{tabular}

Keterangan/Note: Notasi huruf yang tidak sama pada kolom yang sama menunjukkan berbeda nyata $(P<0,05) /$ Different characters at the same column show significant difference $(P<0.05)$ 
Beras analog yang dihasilkan memiliki densitas kamba yang berkisar antara $0,53-0,57 \mathrm{~g} / \mathrm{ml}$. Hasil analisis statistik menunjukkan tidak ada pengaruh penambahan tepung rumput laut terhadap densitas kamba beras analog yang dihasilkan. Densitas kamba beras analog hasil penelitian Muslikatin (2012) berkisar $0,57-0,69 \mathrm{~g} / \mathrm{ml}$. Jika dibandingkan dengan beras analog hasil penelitian Muslikatin (2012), maka densitas kamba beras analog hasil penelitian lebih rendah. Menurut Widara (2012), densitas kamba beras analog yang rendah menunjukkan beras analog memiliki porositas yang tinggi, yang dapat dipengaruhi oleh kandungan gizi beras analog maupun proses pembuatan.

Waktu tanak beras analog merupakan parameter mutu fisik yang penting dalam pemasakan beras analog. Rata-rata waktu tanak beras analog berkisar antara 11-13 menit. Waktu tanak beras analog dengan penambahan tepung rumput laut $7 \%$ adalah 13 menit, sedangkan waktu tanak dari beras analog dengan penambahan tepung rumput laut $0-5 \%$ adalah 11 menit. Penelitian yang dilakukan Muslikatin (2012) menunjukkan waktu tanak nasi yang berasal dari beras analog berbahan dasar beras menir yang ditambah tepung rumput laut berkisar antara 17-18 menit. Waktu yang dibutuhkan untuk memasak beras analog hasil penelitian lebih rendah jika dibandingkan penelitian Muslikatin (2012).

\section{Komposisi Proksimat Beras Analog}

Hasil analisis komposisi proksimat beras analog disajikan pada Tabel 3. Kadar air merupakan salah satu faktor penting dalam pembuatan beras analog, karena kadar air yang tinggi menyebabkan beras analog yang dihasilkan akan mudah mengalami kerusakan. Menurut Winarno (2008) kandungan air dari bahan berperan penting dalam mempertahankan daya awet bahan, semakin rendah kadar air semakin awet bahan tersebut. Hasil pengujian kadar air pada beras analog menunjukkan bahwa kadar air berkisar antara $8,44-8,88 \%$. Hasil analisis statistik menunjukkan tidak ada pengaruh penambahan tepung rumput laut terhadap kadar air beras analog yang dihasilkan.

Kadar abu suatu bahan berkaitan dengan kandungan mineral pada bahan tersebut (Winarno, 2008). Kadar abu beras analog yang dihasilkan berkisar antara 1,27-2,34\% (bk). Hasil analisis statistik menunjukkan tidak ada pengaruh penambahan tepung rumput laut terhadap kandungan abu dari beras analog. Namun nilai rata-rata kandungan abu semakin meningkat dengan meningkatnya jumlah tepung rumput laut yang ditambahkan. Hal ini disebabkan rumput laut banyak mengandung mineral. Unsur mineral juga dikenal sebagai zat anorganik atau kadar abu (Winarno, 2008).

Kandungan protein dari beras analog yang dihasilkan berkisar antara 0,86-1,13\% (bk). Hasil analisis statistik menunjukkan tidak ada pengaruh penambahan tepung rumput laut terhadap kandungan protein beras analog yang dihasilkan. Dari hasil penelitian yang dilakukan oleh Setianingsih (2008) beras IR-64 mengandung protein sebesar 10,9\% sehingga masih perlu melakukan penelitian lanjutan yang mengkombinasikan sumber bahan lain agar beras analog yang dihasilkan dapat mendekati kadar protein beras asli. Tepung rumput laut yang digunakan pada penelitian ini mengandung protein cukup besar yaitu sebesar $7,91 \%$, namun penambahan tepung rumput laut sebesar $7 \%$ belum mampu meningkatkan kandungan protein dari beras analog.

Lemak adalah senyawa yang bersifat tidak larut air, namun larut dalam pelarut organik. Kadar lemak beras analog yang dihasilkan berkisar antara 0,01$0,18 \%$ (bk). Hasil analisis statistik menunjukkan tidak terlihat adanya pengaruh penambahan tepung rumput laut terhadap kadar lemak beras analog yang dihasilkan. Hal ini juga terjadi pada penelitian

Tabel 3. Komposisi proksimat beras analog (bk)

Table 3. Proximate composition of rice analogues (db)

\begin{tabular}{cccccc}
\hline $\begin{array}{c}\text { Penambahan Tepung } \\
\text { Rumput Laut/ } \\
\text { Seaweed Flour Addition }\end{array}$ & $\begin{array}{c}\text { Air/ } \\
\text { Moisture } \\
\text { (\%) }\end{array}$ & $\begin{array}{c}\text { Abu/ } \\
\text { Ash } \\
(\%)\end{array}$ & $\begin{array}{c}\text { Protein/ } \\
\text { Protein } \\
\text { (\%) }\end{array}$ & $\begin{array}{c}\text { Lemak/Fat } \\
\text { (\%) }\end{array}$ & $\begin{array}{c}\text { Karbohidrat/ } \\
\text { Carbohydrate by } \\
\text { Difference (\%) }\end{array}$ \\
\hline $0 \%$ & $8.58^{\mathrm{a}}$ & $1.27^{\mathrm{a}}$ & $0.93^{\mathrm{a}}$ & $0.01^{\mathrm{a}}$ & $89.21^{\mathrm{a}}$ \\
$3 \%$ & $8.44^{\mathrm{a}}$ & $1.63^{\mathrm{a}}$ & $1.12^{\mathrm{a}}$ & $0.00^{\mathrm{a}}$ & $88.81^{\mathrm{a}}$ \\
$5 \%$ & $8.76^{\mathrm{a}}$ & $1.96^{\mathrm{a}}$ & $0.86^{\mathrm{a}}$ & $0.15^{\mathrm{a}}$ & $88.28^{\mathrm{a}}$ \\
$7 \%$ & $8.88^{\mathrm{a}}$ & $2.34^{\mathrm{a}}$ & $1.13^{\mathrm{a}}$ & $0.18^{\mathrm{a}}$ & $87.47^{\mathrm{a}}$ \\
\hline
\end{tabular}

Keterangan/Note: Notasi huruf yang sama pada kolom yang sama menunjukkan tidak ada perbedaan $(P>0,05) /$ Same letter in the same column shows not significant $(P>0.05)$ 
Muslikatin (2012), bahwa penambahan tepung rumput laut 3-7\% tidak berpengaruh nyata pada beras analog dari bahan dasar beras menir dengan teknologi ekstrusi. Kadar lemak beras analog hasil penelitian Muslikatin (2012) berkisar antara 0,34-0,62\% (bb). Beras analog memiliki kadar lemak yang rendah sehingga tidak mudah mengalami ketengikan.

Karbohidrat merupakan sumber gizi utama yang diharapkan dari mengkonsumsi beras sebagai sumber energi. Karbohidrat yang terkandung pada beras analog adalah berkisar antara 88,81-89,21\% (bk). Karbohidrat adalah zat gizi yang terdapat dalam jumlah besar pada beras. Hasil analisis statistik menunjukkan tidak ada pengaruh penambahan tepung rumput laut terhadap kandungan karbohidrat dari beras analog yang dihasilkan. Penambahan tepung rumput laut 3-7\% pada beras analog dari bahan dasar beras menir menghasilkan kadar karbohidrat berkisar antara 79,57-81,82\% (bb) (Muslikatin, 2012). Beras amilosa sedang jenis IR-64 memiliki kadar karbohidrat $88 \%$ (bk), sedangkan beras sosoh memiliki karbohibrat sebesar $89,56 \%$ (bk) (Ohtsubo et al. 2005).

\section{Sifat Sensori Beras Analog}

Uji sensori dilakukan terhadap beras analog dan nasi yang disiapkan dari beras analog (beras analog yang telah dimasak). Pengujian sensori beras analog yang dilakukan meliputi warna, aroma, tekstur dan penerimaan keseluruhan, sedangkan terhadap nasi analog meliputi warna, aroma, kelengketan, tekstur, rasa dan penerimaan umum.

\section{Beras Analog}

Hasil pengujian sensori terhadap beras analog yang dihasilkan dapat dilihat pada Tabel 4 . Penerimaan panelis terhadap atribut warna berkisar dari nilai 3,475,67 yang menunjukkan panelis agak tidak suka hingga suka terhadap warna beras analog yang dihasilkan. Hasil analisis statistik menunjukkan bahwa penambahan tepung rumput laut berpengaruh sangat nyata terhadap warna beras analog. Panelis menyukai warna beras analog tanpa penambahan tepung rumput laut dengan nilai 5,67 artinya panelis agak suka hingga suka terhadap warna beras analog yang tidak ditambahkan tepung rumput laut. Nilai tersebut tidak berbeda nyata dengan warna beras analog dengan penambahan tepung rumput laut $5 \%$. Nilai warna paling rendah adalah pada perlakuan penambahan tepung rumput laut $7 \%$ dengan nilai 3,47 yang menunjukkan panelis agak tidak suka hingga netral terhadap warna beras analog yang dihasilkan. Secara visual beras analog tanpa penambahan maupun dengan penambahan tepung rumput laut $5 \%$ berwarna putih kekuningan cerah, sedangkan beras analog dengan penambahan tepung rumput laut $7 \%$ mempunyai warna kuning kecoklatan. Warna tepung mocaf sebagai bahan dasar beras analog memiliki warna putih, sedangkan tepung rumput laut memiliki warna kuning kecoklatan. Hal ini diduga sebagai penyebab perubahan warna beras analog yang dihasilkan. Semakin tinggi penambahan tepung rumput laut, warna kuning kecoklatan pada beras semakin kuat. Panelis lebih suka beras analog yang memiliki warna putih kekuningan dan cerah. Penambahan tepung rumput laut pada beras ekstrusi menyebabkan warna beras ekstrusi menjadi putih kusam, dan semakin tinggi penambahan tepung rumput laut warna kusam semakin kuat (Muslikatin, 2012). Warna merupakan salah satu atribut penting yang menentukan faktor penerimaan pangan oleh konsumen.

Nilai penerimaan panelis terhadap aroma berkisar antara $4,60-4,80$ yaitu netral hingga agak suka. Hasil

Tabel 4. Hasil uji sensori beras analog

Table 4. Results sensory evaluation of rice analogues

\begin{tabular}{ccccc}
\hline \multirow{2}{*}{$\begin{array}{c}\text { Penambahan Tepung } \\
\text { Rumput Laut/Seaweed } \\
\text { Flour Addition }\end{array}$} & \multicolumn{4}{c}{ Parameter/Parameters } \\
\cline { 2 - 5 } & $\begin{array}{c}\text { Warna/ } \\
\text { Colour }\end{array}$ & $\begin{array}{c}\text { Aroma/ } \\
\text { Flavour }\end{array}$ & $\begin{array}{c}\text { Tekstur/ } \\
\text { Texture }\end{array}$ & $\begin{array}{c}\text { Keseluruhan/ } \\
\text { Overall }\end{array}$ \\
\hline $0 \%$ & $5.67^{\mathrm{b}}$ & $4.80^{\mathrm{a}}$ & $4.60^{\mathrm{a}}$ & $5.23^{\mathrm{a}}$ \\
$3 \%$ & $4.27^{\mathrm{a}}$ & $4.67^{\mathrm{a}}$ & $4.53^{\mathrm{a}}$ & $4.40^{\mathrm{a}}$ \\
$5 \%$ & $4.73^{\mathrm{ab}}$ & $4.80^{\mathrm{a}}$ & $4.53^{\mathrm{a}}$ & $4.53^{\mathrm{a}}$ \\
$7 \%$ & $3.47^{\mathrm{a}}$ & $4.60^{\mathrm{a}}$ & $4.67^{\mathrm{a}}$ & $4.17^{\mathrm{a}}$ \\
\hline
\end{tabular}

Keterangan/Note: Notasi huruf yang tidak sama pada kolom yang sama menunjukkan berbeda nyata $(P<0,05) /$ Different characters at the same column show significant difference $(P<0.05)$ 
analisis statistik menunjukkan tidak ada pengaruh penambahan tepung rumput laut terhadap aroma beras analog. Tepung rumput laut yang digunakan memiliki aroma netral (tidak berbau), sehingga tidak mempengaruhi aroma beras analog yang dihasilkan.

Pengujian tekstur untuk melihat kerapuhan/ kemudahan patah dari beras yang dihasilkan. Semakin kuat dan tidak rapuh beras semakin baik beras analog yang dihasilkan. Panelis memberikan nilai tekstur berkisar antara 4,53-4,67 artinya berkisar antara netral hingga agak suka. Hasil analisis statistik menunjukkan tidak ada pengaruh penambahan tepung rumput laut terhadap tekstur beras analog. Secara diskriptif tekstur beras analog yang ditambah dengan tepung rumput laut kompak/tidak rapuh, dan agak keras.

Nilai kesukaan panelis secara keseluruhan terhadap beras analog yang dihasilkan berkisar antara $4,17-5,23$ yang artinya panelis memberikan kesan netral hingga suka terhadap beras analog. Hasil analisis statistik menunjukkan tidak ada pengaruh penambahan tepung rumput laut terhadap kesukaan keseluruhan beras analog. Panelis tidak dapat membedakan secara tegas perbedaan beras analog akibat penambahan rumput laut. Hal ini kemungkinan karena penambahan tepung rumput laut jumlahnya sedikit sehingga tidak berdampak terhadap beras analog yang dihasilkan. Tepung rumput laut $E$. cottonii mengandung karaginan yang memiliki sifat dapat membentuk gel dan akan mempengaruhi terhadap profil tekstur pada produk pangan yang ditambah tepung rumput laut. Penambahan tepung rumput laut dengan konsentrasi yang semakin tinggi diduga akan menyebabkan mutu sensori beras analog berbahan dasar mocaf yang dihasilkan berbeda nyata, pada parameter warna akan semakin kecoklatan dan pudar, serta tekstur semakin keras, yang menyebabkan beras analog tidak disukai panelis. Beras analog dengan penambahan tepung rumput laut $5 \%$ menghasilkan nilai warna, aroma, dan kesukaan secara keseluruhan tertinggi dibandingkan dengan penambahan 3 dan $7 \%$. Pada beras analog dengan perlakuan penambahan tepung rumput laut sebesar $5 \%$ panelis memberikan nilai rata-rata sebesar 4,53 , yaitu netral hingga agak suka. Berdasarkan hasil analisis tersebut maka dalam bentuk mentahnya beras analog dengan penambahan tepung rumput laut $5 \%$ dianggap paling diterima panelis.

\section{Nasi Analog}

Pengujian sensori terhadap nasi analog atau beras analog matang dilakukan untuk melihat penerimaan panelis terhadap beras analog yang telah dimasak. Hasil pengujian sensori terhadap nasi analog untuk masing-masing atribut dapat dilihat pada Tabel 5.

Nilai yang diberikan panelis terhadap atribut warna nasi analog berkisar antara 3,27-5,47 artinya panelis agak tidak suka hingga suka terhadap warna nasi beras analog yang dihasilkan. Hasil analisis statistik menunjukkan penambahan tepung rumput laut berpengaruh terhadap warna nasi analog. Panelis lebih menyukai warna nasi analog tanpa penambahan tepung rumput dengan nilai 5,47 (agak suka hingga suka) yang nilainya tidak berbeda nyata dengan perlakuan penambahan tepung rumput laut $5 \%$. Secara umum terlihat penambahan tepung rumput laut menyebabkan menurunnya kesukaan panelis terhadap warna nasi analog karena menyebabkan nasi analog yang dihasilkan lebih kuning. Dengan demikian dapat disimpulkan bahwa panelis masih mengharapkan nasi analog yang berwarna putih seperti halnya nasi dari beras asli. Hal ini sesuai

Tabel 5. Hasil uji sensori nasi analog

Table 5. Results sensory evaluation of cooking rice analogues

\begin{tabular}{|c|c|c|c|c|c|}
\hline \multirow{2}{*}{$\begin{array}{l}\text { Penambahan Tepung } \\
\text { Rumput Laut/ } \\
\text { Seaweed Flour Addition }\end{array}$} & \multicolumn{5}{|c|}{ Parameter/Parameters } \\
\hline & $\begin{array}{l}\text { Warnal } \\
\text { Colour }\end{array}$ & $\begin{array}{l}\text { Aromal } \\
\text { Flavour }\end{array}$ & $\begin{array}{l}\text { Kelengketan/ } \\
\text { Stickiness }\end{array}$ & $\begin{array}{l}\text { Rasa/ } \\
\text { Taste }\end{array}$ & $\begin{array}{c}\text { Keseluruhan/ } \\
\text { Overall }\end{array}$ \\
\hline $0 \%$ & $5.47^{b}$ & $3.93^{\mathrm{a}}$ & $4.47^{\mathrm{a}}$ & $4.67^{\mathrm{a}}$ & $5.13^{\mathrm{a}}$ \\
\hline $3 \%$ & $3.93^{\mathrm{a}}$ & $3.87^{\mathrm{a}}$ & $3.93^{\mathrm{a}}$ & $4.40^{\mathrm{a}}$ & $4.10^{\mathrm{a}}$ \\
\hline $5 \%$ & $4.47^{\mathrm{ab}}$ & $3.93^{\mathrm{a}}$ & $4.07^{\mathrm{a}}$ & $4.20^{\mathrm{a}}$ & $4.40^{\mathrm{a}}$ \\
\hline $7 \%$ & $3,27^{\mathrm{a}}$ & $3,47^{\mathrm{a}}$ & $3.33^{\mathrm{a}}$ & $3.87^{\mathrm{a}}$ & $3.87^{\mathrm{a}}$ \\
\hline
\end{tabular}

Keterangan/Note: Notasi huruf yang tidak sama pada kolom yang sama menunjukkan berbeda nyata $(P<0,05) /$ Different characters at the same column show significant difference $(P<0.05)$ 
dengan yang dinyatakan oleh Mishra et al. (2012), bahwa presepsi konsumen terhadap warna nasi sangat penting agar beras tersebut dapat diterima oleh konsumen.

Nilai yang diberikan panelis terhadap atribut aroma nasi analog berkisar antara 3,47-3,93, dengan kriteria agak tidak suka hingga netral. Hasil analisis statistik menunjukkan penambahan tepung rumput laut tidak berpengaruh nyata terhadap aroma nasi analog. Tepung rumput laut beraroma netral dan jumlah yang digunakan sedikit sehingga tidak menyebabkan perubahan aroma nasi analog berbahan dasar mocaf.

Kelengketan adalah salah satu atribut penting dalam pengujian beras analog. Kelengketan merupakan tekstur utama yang mewakili tingkat kepulenan dari beras yang dihasilkan. Nilai yang diberikan panelis terhadap tingkat kelengketan nasi analog berkisar antara 3,3-4,47 (agak tidak suka hingga agak suka). Hasil analisis statistik menunjukkan penambahan tepung rumput laut tidak berbeda nyata terhadap penerimaan panelis pada atribut kelengketan. Nilai rata-rata kelengketan nasi analog dengan penambahan tepung rumput laut $7 \%$ memiliki nilai yang terendah yaitu 3,3 , secara diskriptif agak tidak disukai karena lengket dan kenyal. Tepung rumput laut $E$. cottonii mengandung kappa karaginan, dengan adanya penambahan air dan proses pemanasan pada pembuatan beras analog maka karaginan akan membentuk gel dan tepung mocaf mengalami gelatinisasi. Pada penambahan tepung rumput laut $7 \%$ nasi analog yang dihasilkan semakin lembek dan berair, dan hal ini tidak disukai oleh panelis.

Rasa merupakan salah satu atribut yang sangat penting pada nasi analog yang dihasilkan. Secara umum panelis memberikan nilai rasa berkisar antara 3,87-4,67 (agak tidak suka hingga agak suka) pada nasi analog yang dihasilkan. Hasil analisis statistik menunjukkan tidak ada pengaruh penambahan tepung rumput laut terhadap rasa nasi analog. Panelis paling menyukai rasa nasi analog tanpa penambahan tepung rumput laut dengan nilai 4,67 (netral hingga agak suka). Penambahan tepung rumput laut $7 \%$ memiliki nilai rata-rata terendah yaitu 3,87 (agak tidak suka hingga netral). Hal ini karena beras analog yang diolah dengan penambahan tepung rumput laut $7 \%$ menghasilkan nasi yang kurang enak, dengan rasa hambar sehingga panelis menyatakan agak tidak suka.

Secara keseluruhan panelis menyukai nasi analog tanpa penambahan tepung rumput laut dengan nilai 5,13 (agak suka hingga suka) dan diikuti dengan nasi analog dengan penambahan tepung rumput laut $5 \%$ dengan nilai 4,40 (netral hingga agak suka).
Penambahan tepung rumput laut sebesar $7 \%$ menghasilkan nasi analog dengan penerimaan keseluruhan terendah yaitu sebesar 3,87 (agak tidak suka hingga netral). Nasi analog dengan penambahan tepung rumput laut $5 \%$ memiliki nilai rata-rata lebih tinggi dari parameter warna, aroma, kelengketan, dan penerimaan secara keseluruhan dibandingkan dengan nasi analog dengan penambahan tepung rumput laut 3 dan $7 \%$.

\section{Pemilihan Formula Terbaik}

Penentuan perlakuan konsentrasi penambahan tepung rumput laut pada formula terpilih didasarkan pada hasil uji sensori beras dan nasi analog yang memiliki nilai rata-rata kesukaan tertinggi dan kandungan serat pangan serta iodium. Dari hasil sensori menunjukkan beras analog dengan penambahan tepung rumput laut $5 \%$ memiliki nilai rata-rata tertinggi pada parameter penerimaan keseluruhan, warna dan aroma sedangkan nasi analog pada parameter penerimaan keseluruhan, warna, aroma dan kelengketan. Oleh karena itu, beras analog dengan penambahan tepung rumput laut sebesar $5 \%$ berdasarkan uji sensori dipilih sebagai perlakuan terbaik.

Kandungan serat pangan beras analog berkisar antara 46,53-58,75\%. Semakin tinggi konsentrasi tepung rumput laut semakin meningkat kandungan serat pangan beras analog. Penambahan tepung rumput laut berpengaruh nyata terhadap kandungan serat pangan beras analog (Muslikatin, 2012). Hal ini karena kandungan serat pangan dari tepung rumput laut lebih besar daripada tepung mocaf. Tingginya kandungan serat rumput laut tidak terlepas dari komponen karbohidratnya yang mencapai $33-50 \%$ bk (Ruperez \& Saura-Calixto, 2001). Beras analog dengan penambahan tepung rumput laut $5 \%$ merupakan perlakuan terbaik yang memiliki kandungan serat pangan $49,76 \mathrm{~g} / 100 \mathrm{~g}$. Peraturan Uni Eropa (EC) No. 1924/2006 (OJ 409P92006/12/30) tentang gizi dan klaim kesehatan pada pangan menetapkan suatu pangan dapat diklaim mengandung tinggi serat jika mengandung paling sedikit 6 gram total serat per 100 gram produk (Muslikatin, 2012). Hal ini berarti menurut persyaratan Uni Eropa (EC), beras analog dengan penambahan tepung rumput laut $5 \%$ sudah mememuhi persyaratan sebagai bahan pangan tinggi serat. Menurut Jahari \& Sumarno (2001) angka kecukupan gizi (AKG) rata-rata serat pangan perhari yang dianjurkan adalah sebesar $30 \mathrm{gram}$, artinya dengan mengkonsumsi beras analog sebesar $61 \mathrm{~g} /$ hari sudah mampu memenuhi kebutuhan AKG serat pangan perhari.

Kandungan iodium dari beras analog berkisar antara 22,91-28,79 ug/g. Beras analog tanpa 
penambahan tepung rumput laut mengandung iodum terendah yaitu $22,91 \mathrm{ug} / \mathrm{g}$ dan beras analog dengan penambahan tepung rumput laut $7 \%$ memiliki kandungan iodium tertinggi yaitu $28,79 \mathrm{ug} / \mathrm{g}$. Penambahan tepung rumput berpengaruh nyata terhadap kandungan iodium beras analog. Semakin tinggi konsentrasi penambahan tepung rumput laut semakin meningkat kandungan iodium beras analog. Kandungan iodium beras analog dengan penambahan tepung rumput laut $5 \%$ adalah $24,98 \mu \mathrm{g} / \mathrm{g}$. Menurut Depkes (1994) AKG rata-rata yang dianjurkan per orang per hari untuk remaja mulai 10 tahun hingga orang dewasa lebih dari 60 tahun adalah sebesar 150 $\mu \mathrm{g} /$ hari, artinya dengan mengkonsumsi beras analog sebesar 6-7 g sudah mampu memenuhi kebutuhan AKG iodium. Nilai tersebut dihitung dari tingkat retensi iodium tepung rumput laut akibat pemanasan yaitu sebesar 14\% (Astawan et al., 2004). Menurut Nurachman dan Hadi (2003) keuntungan konsumsi iodium melalui makanan laut adalah elemen iodium tersebut tidak hilang selama proses pemasakan.

\section{KESIMPULAN}

Beras analog berbahan dasar tepung mocaf dengan penambahan tepung rumput laut Eucheuma cottonii $5 \%$ lebih disukai panelis berdasarkan nilai rata-rata tertinggi uji sensori kesukaan dan mutu atribut sensori warna dan aroma pada beras mentah dan nilai rata-rata tertinggi uji kesukaan dan mutu atribut sensori warna, aroma dan kelengketan pada nasi analog. Karakteristik mutu beras analog tersebut memiliki densitas kamba $0,57 \mathrm{~g} / \mathrm{ml}$, derajat putih $17,70 \%$, kadar air 8,76\%, kadar abu 1,96\%, kadar protein $0,86 \%$, kadar lemak $0,15 \%$, serat pangan $49,76 \%$, iodium $24,98 \mathrm{ug} / \mathrm{g}$ dan rendemen $99 \%$. Beras analog belum mirip menyerupai bentuk beras asli, tetapi memiliki bentuk silinder berukuran 3-5 $\mathrm{mm}$.

\section{DAFTAR PUSTAKA}

AOAC. (2004). Official Method of Analysis. AOAC, Washington

Ashong, J., Muthayya, S., \& Lm, D. (2012). Fortification of rice with vitamins and minerals for addressing micronutrient malnutrition (Protocol). The Cochrane Library 2012. p. 1-20.

Asp, N.G., Johanson, C., Halmer, H., \& Siljestom. (1983). Rapid enzymatic assay of insoluble and soluble dietary fiber. Journal of Agricultural and Food Chemistry. 31: 476-482.

Astawan, M., Koswara, S., \& Herdiani, F. (2004). Kadar lodium dan Serat Pangan Pada Selai dan Dodol [The Utilization of Seaweed (Eucheuma cottonii) to Increase lodine and Dietary Fiber Contents of Jam and Dodol ]. XV:
Astawan, M., Wresdiyati, T., \& Hartanta, A.B. (2005). Pemanfaatan rumput laut sebagai sumber serat pangan untuk menurunkan kolesterol darah tikus. Hayati. 12: 23-27.

Budijanto, S. \& Yuliyanti. (2012). Studi persiapan tepung sorgum (Sorghum bicolor L. Moench) dan aplikasinya pada pembuatan beras analog. Jurnal Teknologi Pertanian. 13(3): 177-186.

Depkes. (1994). Angka Kecukupan Gizi yang Dianjurkan Bagi Bangsa Indonesia. Keputusan Menkes RI No.322/Menkes/SK/IV/1994, Indonesia.

Dewi, R.K. (2012). Rekayasa Beras Analog Berbahan Dasar Modified Cassava Flour (Mocaf) dengan Teknologi Ekstrusi. Skripsi. Fakultas Teknologi Pertanian. Institut Pertanian Bogor. 75 pp.

Diehl, J.C. (1988). Imitation Ceremonial Rice. United States Patent. doi: 5547719

Herawati, H. \& Widowati S. (2009). Karakteristik beras mutiara dari ubi jalar (Ipomea batatas). Buletin Teknologi Pascapanen Pertanian. 5:37-44.

Herpandi, Astawan, M., Wresdiyati, T., \& Palupi N.S. (2006). Perubahan profil lipida, kolesterol digesta dan asam propionat pada tiikus dengan diet tepung rumput laut. Jurnal. Tekno. dan Industri Pangan. XVII(3): 227-231.

Ichikawa, K. \& Chiharu, M. (2007). Method of producing artificialrice from soybean employed as the main starting material and artiûcial rice produced by the method.http://www. wipo.int/pctdb/en/ wo.jsp? $W O=2007055122$. Accessed 29 November 2011

Jahari, A. \& Sumarno, I . (2001). Tingkat Konsumsi Serat Penduduk di Indonesia. Media Gizi dan Keluarga. Jurusan Gizi Masyarakat dan Sumberdaya Keluarga. Fakultas Pertanian, IPB, Bogor. Kristianto.

Kato K . 2006. Soy-based rice substitute. 0060073259:110.

Li, Y., Diosady, L.L., and Jankowski, S. (2008). Effect of iron compounds on the storage stability of multiplefortified Ultra Rice Ò. International Journal of Food Science and Technology. 43:423-429. doi: 10.1111/ j.1365-2621.2006.01457.x

Mishra, A., Mishra, H.N., \& Rao, P.S. (2012). Review preparation of rice analogues using extrusion technology. 1789-1797. doi: 10.1111/j.13652621.2012.03035.x

Moretti, D., Zimmermann, M.B., \& Muthayya, S. (2006). Extruded rice fortified with micronized ground ferric pyrophosphate reduces iron deficiency in Indian schoolchildren: a double-blind randomized controlled trial. The American Journal of Clinical Nutrition. 84: 822-9.

Muslikatin (2012). Pengembangan Beras Ekstrusi (Extruded Rice) Kaya Serat Dengan Penambahan Tepung Rumput Laut (Eucheuma cottoni). IPB, Bogor

Nurachman, Z. \& Hadi, S. (2003). Seberapa Efektifkah Garam Beryodium. Kompas

Ohtsubo, K., Suzuki, K., Yasui, Y., \& Kasumi, T. (2005). Bio-functional component in the processed pregerminated brown rice by a twin screw exstruder. 
Journal of Food Compositions and Analisys 18: 303316.

Prasetia, H.A. (2009). Perbaikan Mutu Beras Ubi dengan Penggunaan Pati Ubi Jalar (Ipomea batats L.) Termodifikasi dengan Heat Moisture Tratment (HMT). IPB. Bogor

Ruperez, P. \& Saura-Calixto, F. (2001). Dietary fibre and physicochemical properties of edible Spanish Seaweeds. Eur. Food Res. Technol. 212: 349-354

Samad, MY. (2003). Pembuatan beras tiruan. Prosiding Seminar Teknologi untuk Negeri. p. 34-60

Setianingsih, P. (2008). Karakteristik Sifat Fisiko Kimia dan Indeks Glikemik Beras Berkadar Amilosa Sedang. Institut Pertanian Bogor, Bogor.

Subagio, A. (2006). Ubi Kayu : Subtitusi Berbagai Tepung-Tepungan. Food review, April 2006. p. 18-22
Widara, S.S. (2012). Studi Pembuatan Beras Analog dari Berbagai Sumber Karbohidrat Menggunakan Teknologi Hot Extrusion. Skripsi. Fakultas Teknologi Pertanian. Institut Pertanian Bogor, Bogor.

Widowati, S., Richana, S., Suismono, \& Herawati, H. (2008). Pengembangan Pangan Pokok Berbasis Pangan Lokal. Laporan Akhir Tahun Rencana Penelitian Tim Peneliti Tahun 2008. Balai Besar Penelitian dan Pengembangan Pascapanen Pertanian.

Winarno, F.G. (2008). Kimia Pangan dan Gizi. Edisi Terbaru. Mbrio Press, Bogor.

Wirakartakusumah M., Abdullah, K., \& Syarief, A. (1992). Sifat Fisik Pangan. PAU Pangan dan Gizi, IPB, Bogor. 